\title{
Museums: Advocator of Urban Cultural Image
}

\author{
Mei XIE ${ }^{1}$, Li-Hua HUANG ${ }^{2, *}$ \\ ${ }^{1}$ Mei Xie, professor of School of Political Science and Public Administration in University of \\ Electronic Science and Technology of China, Chongqing, China
}

${ }^{2}$ Lihua Huang, graduate student of Journalism and communication major in University of Electronic Science and Technology of China, Jining, Shandong, China

Xiemei001@163.com,Lihuahuang89@163.com

*Lihua Huang

Key words: museum, urban culture, cultural image, endorsement

\begin{abstract}
Urban museums witness the venation of urban cultural development what is the carrier of urban cultural memory, which massive cultural connotation and unique appearance appear personality and characteristic of urban characteristic. Collection of museum is the root of culture; exhibition activity of museum is cultural extension; and museum architecture is the combination between history and reality. For this purpose, the article discusses rich cultural connotation and appears the endorsement function of outer image of urban cultural from museum collections, exhibition activities, museum architecture and other elements. Museum met some new challenges and issues as advocator of urban cultural image is worth to explore by today's Chinese urban museum.
\end{abstract}

\section{Introduction}

In the development of urban culture, museum has a vital status what is advocator of urban culture, which likes Louvre Museum in Paris, British Museum in London and Metropolitan Museum in New York. The construction of museum gradually becomes popular in the process of urban culture construction, and we can see a lot of museums in construction or expansion in cities with assorted proportions in the globe. As a kind of world cultural phenomenon, urban museums transform themselves as well as make urban development become more energetic. The urban museum culture like art exhibition and expo has become a mark of urban culture developed. Museum represents the development level of urban culture that leads the cultural direction of urban healthy, civilization and high grade.

The basic definition of International Council of Museums is that museum is a published non-profit permanent institution that services for society and development. It is a physical evidence to collect, project, research, spread and show the human and the human environment for education and appreciation. [1] In the 21st century, museum culture has infiltrated into people's life which is not a traditional position to collect, display and custody cultural relic, but a diversified and multi-function service facility of cultural education and communication. Nowadays function of museum is constantly developing by human's demand, and also appeared the concept of "living condition of museum" and "opening museum". Connotation and outside of museum are rapidly increasing, and range of space is also increasing. In addition, museum also further perfect urban leisure tourism, youth quality education, enterprise culture exhibition, advertisement and some other functions [2]. Museums have benign interaction with urban culture construction and promote the development of urban culture by expanding service function.

\section{Museum: Endorsement of Urban Culture Connotation}

Historical culture is the foundation and connotation for a city. Museum appeared by the city, which is the most abundant location to intensively collect and exhibit the urban historical and cultural resources to represent the development and maturity of the urban culture. Urban museum 
rose in the 1970s that endowed intelligence of urban sprit and artistic conception of culture with its profound cultural accumulation and incomparable advantage of cultural symbol. The associate librarian of Deutsches Historisches Museum, Dr Hans Martin sheen, who ever said, "An urban museum plays a very important role in building a civilized society. A country would be a poor country with no museums in the city", when celebrated the earliest Chinese museum--the 100th anniversary of the Nantong museum garden and Chinese museum development, which is set by patriotic industrialist in later Qing dynasty, Zhang jian [3].

\section{Museum Collections is the Source of Cultural Connotation}

Urban museum exhibits the most brilliant and shine history by collecting, protecting and researching cultural relics collections and cultural heritages, to present historical context of urban cultural development and outstanding national spirit, which makes people learn much more historic knowledge, humanistic sprit and extraordinary entrepreneurial journey of generation predecessors, and understand the seemingly distant history that is today's foundation and soul of urban cultural development. We are proud of the civilization history and excellent national spirit [4]. Chengdu JINSHA Site Museum has rich collections. The unearthed the golf foil of "Sunbird" with the pattern of four birds around with smooth lines, elegant modeling and profound meaning which left a deep imprint in Chengdu citizens' heart after media reports. Everybody is impressed of exquisite design and craftsmanship by the ancient Shu Dynasty people. From now onwards it closely linked with historical civilization of long history of Cheng Du, like Tianfu interchange of People South Street Chengdu, New Tianfu Square of Cheng Du and other important locations are frequently appeared "Sunbird". In JINSHA Site Museum, some other cultural relics that unearthed together with "Sunbird" are greatly enrich the culture of Cheng Du and add new energetic of urban culture.

\section{Museum Exhibition and Other Activities is the Extend of Cultural Connotation}

Display and exhibition is the coral cultural products of museum, a life of museum and the basic method of museum extension of city culture. "Better city, better life" of Shanghai World Expo in 2010 deduces urban theme, continues urban contexts and features closely connections of world expo and urban. After successfully hosting of World Expo, non-substitutable step of museum get recognize in continuation of urban culture connotation in urban social cultural system. The museum itself has incomparable physical advantages. Not only urban museum develops the basic public service function, but also takes full advantage of collections and talents to provide characteristic spiritual and cultural products. It planned positive cultural connotations of display and exhibition, academic forum and other activities. On the one hand, it greatly rich civic life and makes prosperity of urban culture that is benefit to the improvement of residents' cultural qualities; on the other hand, the generalization of museum exhibition and other activities arouse local citizens to notice some other cultural characteristics that different from other regions, and also make nonlocal people find characteristics of historical and cultural in this city.

Urban museum forwards in explore innovation, and adhere to the road of close to the people, as well as the development of public service. Deeper into the social public life, because abroad a lot of political activities and social activities would chose in museum, which up to meet of head of state and down to the community activities. The atmosphere is very solemn with high grade, which makes urban culture and cultural spirit of the city exhibit and spread. In domestic, most of the museums become patriotism education base. The museum opened display and exhibition is very intuitive and vivid that makes the evidence of history and cultural relic, to spread the information of ideological education and help citizens to arouse national pride, self-confidence and patriotism. In addition, museum is the window of cultural exchange that constantly bring excellent culture of different ground amorous feelings into the local region with introduction and exchange of exhibition, to extremely rich cultural life of urban citizens and promote flourishing development of urban culture. 


\section{Museum Architecture: Endorsement of Urban External Cultural Image}

The famous American urban planning expert, Eero Saarinen ever said, "let us see your city, and we will understand what is the urban citizens pursues." [5] For the features of a modern city, not only have the spirit of the times, but also have profound cultural background and cultural pursuit. As symbolic city landmarks, the integration of history and reality makes museum become one of the best exterior culture statue ambassadors for a city, which is the combination between urban culture and beauty. Solemn and gorgeous Palace Museum lets Beijing famous for overseas and majestic Mausoleum of the First Qin Emperor lets Xi'an known in the world. These museums with unique style are also the valuable cultural resources that add gorgeous shine to the city with strong attraction and social influence.

In the recent years, more and more domestic cities promote the image of urban culture innovation center by museum building. In the urban culture construction, a lot of provinces and cities put museum architecture model on the outstanding position with delicate design and construction to create new urban image. Just as the famous architect JeanNieolas--LouisDurand in the 19th ever said, "The real metropolis has some museums." [6]

In the abroad culture metropolises, the representative is Washington of America that is one of the countries with the largest quantity and the most abundant collections in the world. The museum architect itself of Washington is the carrier of cultural art, like fluctuant line of Indian Museum, circular arcades and zodiac pillar of Museum of Modern Art and glass house body of Museum of the world, that there is no lack of many elements of architectural beauty, like golden Minnesota limestone, winding dome, carved lintel, colorful glass, and etc. They are full of clever under the sunshine to express their personality and reveal their charm of city.

London, the world famous historic and cultural city, is called museum city. People lived or travelled in London all can obviously feel containment for the whole city. Old and new cities have no conflict with structure, material and ingenuity, and the novel design model always can be grafted in several hundred years of Victorian building which is also complement each other. Spectacular British Museum, solemn National Gallery and some other different proportions in the city are sustained by the city's cultural level. British always say, "If lose a Shakespeare, I prefer to lose two India." [7] It explains the enthusiasm for British to culture, and the dotted museums in London also confirm it.

In the domestic cities, architecture of Shanghai Museum can be seen the outstanding representative in the image endorsement of Chinese urban culture. Shanghai is a metropolis which was developed by collision and fusion of modern Chinese and Western culture. Architectural design of Shanghai Museum fully considered about the characteristic of Chinese and Western combined. From the contents to overall control of form, not only pay attention to inherit the essence of Chinese traditional culture to reflect the unique cultural characteristics, but also advanced apply and show up advancement of modern science technology. Shanghai Museum fully reflects cultural deposit and temperament to vastly upgrade cultural status of economy, finance, trade and shipping center.

\section{New Challenge of Image Endorsement of Museum Urban Culture}

Times development adds new functions to the museum. In the urbanization process, construct cultural environment of urban characteristics by museum is the best method to keep competition with nearby cities and international situation and constantly develop the local cultural economy. At nowadays, museums carry the endorsement of urban cultural image, but also meet challenge. Museum was born the city with rich history and humanity. How to make museums maximize develop the function of urban cultural image endorsement? What attitude for museums to face the phenomenon that constructs museums to develop urban culture? What method to keep museums' status in the big condition of improving cultural image that compared with other cultural facilities or take other development methods? What location for museums in the future urban development of construction? These doubts are necessary issues in China city museum, and also the new challenge of museum function for improving urban cultural undertakings. 
Under the new historic situation, we should be clear that the function of museum urban cultural image doesn't isolated and blind but incorporated in to environment of internationalization. Chinese Museum may exist some distance with World Museum as build urban cultural image. Though the difference can't be able to put off in the short term, but Chinese Museum has a lot of improvement and progress in developing the advantage of collections and fully developing self-function to combine new media to have urban image propaganda, having communication and cooperation with abroad and domestic important museums to enhance influence of urban and museum.

\section{Conclusion}

Xu huping, curator of Nanjing Museum, ever put forward "hope each museum becomes the pride and symbol of the city. Let each city has proud and symbolic museum” in Museum and City's Image. [8] Urban museum keeps sustainable competitiveness for city in the cultural construction and supports the heavy responsibility of urban cultural image endorsement as the important of urban culture. City must combine develop economy and protect and make good use of urban cultural resources that promote urban museum construction combined with development of other cultural resources to joint plan to urban cultural developing construction , if people want to let museums play the role of urban cultural image endorsement. Urban museum construction is consistent with cultural tradition and spiritual orientation, and promotion with urban material civilization and spiritual civilization construction to give urban museum new time significance and cultural connotation, as well as play the role of urban cultural image endorsement under the new times.

\section{Acknowledgement}

This article was financially supported by "model research of museology resources of conversion utilization" for National social science fund project in 2014 (Project Number: 14BGL162) and financed by Sichuan Social Science Funds: Research on communicative Chengdu based on the perspective of Chinese culture going out (Project Number: SC15XS007)

\section{Reference:}

[1] International Council of Museums. Article of the 21th general assembly of International Council of Museums in 2007[Z].Vienna, 2007.

[2] Shan jixiang. Consideration of features and functions on museum in the new period [J]. Chinese Museum, 2010, (4): 4-7.

[3][5] Zhang chunpeng. Importance analysis of urban cultural construction in museum importance analysis[J]. Beauty and Age, 2009, 4: 59-61.

[4] Hou aiqing, National consciousness and global consciousness blend of urban culture construction of the museum [C]. Variation of the city memory-memoir of professional committee of city museum of Chinese Museum Association (2013-2014). Published in Shanghai Jiaotong University: professional committee of city museum of Chinese Museum Association,2014: 499-504.

[6] Xiang Bingren\&Wu yunyi. Contemporary Museum Architecture and urban culture [C]. Architectural Journal, 2009, 2: 81-85.

[7] An ping, London: wonderful time of Museum [J]. In\&Out of Class, 2012, 11: 64-65.

[8] Xu huping, Museum and urban image [J]. Journal of Nantong university, 2005, 21(4): 3-4. 